\title{
Use of olive oil and warm water in bathing intervention in preventing risk of skin integrity damage in total care patients with chronic disease: A case study
}

\author{
Maria Pele $^{1 *}$, Agung Waluyo ${ }^{2}$ \\ ${ }^{1,2}$ Faculty of Nursing, Universitas Indonesia, Indonesia \\ *Corresponding email: marpel.com.mp@gmail.com
}

\begin{abstract}
ARTICLE INFO
HOW TO CITED:

Pele, M. and Waluyo, A. (2019). Use of olive oil and warm water in bathing intervention in preventing risk of skin integrity damage in total care patients with chronic disease: A case study. Jurnal Pendidikan Keperawatan Indonesia 5(1), p. 1-6
\end{abstract}

DOI:

10.17509/jpki.v5i1.13966

\section{ARTICLE HISTORY:}

Accepted

December 20, 2018

Revised

April 15, 2019

Published

June 26, 2019

\section{A B S T R A C T}

Chronic disease in total care patients can lead the damage of skin integrity. The skin integrity damage can be affected by various patient's conditions, including physical immobilization, treatment, changes in skin turgor, immune decline, age, environmental changes, and the effects of the diseases. It can make the complications of the patient condition such as infection so that can cause the longer length of stay and higher of hospitalization costs. This research aims to identify the use of olive oil and warm water in bathing intervention in preventing the risk of skin integrity damage in total care patients with chronic disease. This case occurred in a full care patient with chronic illness. The skin integrity was assessed by Braden score while the patient condition assessed through observations. Finding of this study is bathing the patient using olive oil and warm water has a calming effect on the patient and preventing damage to the integrity of the skin. Use of olive oil and warm water in bathing intervention can be avoiding the risk of skin integrity damage in total care patients with chronic disease.

Keywords: Bathing intervention, olive oil, risk of skin integrity damage, skin integrity, warm water bathing

\section{$\boldsymbol{A} \boldsymbol{B} \boldsymbol{S} \boldsymbol{T} \boldsymbol{R} \boldsymbol{A} \boldsymbol{K}$}

Penyakit kronis pada pasien dengan perawatan total dapat menyebabkan kerusakan integritas kulit. Kerusakan integritas kulit dapat dipengaruhi oleh berbagai kondisi pasien, termasuk imobilisasi fisik, perawatan, perubahan turgor kulit, penurunan kekebalan, usia, perubahan lingkungan dan efek penyakit. Hal ini dapat menyebabkan komplikasi pada kondisi pasien seperti infeksi sehingga dapat menyebabkan lama hari rawat lebih lama dan biaya rawat inap yang lebih tinggi. Penelitian ini bertujuan untuk mengidentifikasi penggunaan minyak zaitun dan air hangat dalam intervensi memandikan dalam mencegah risiko kerusakan integritas kulit pada pasien perawatan total dengan penyakit kronis. Penelitian ini merupakan studi kasus pada satu pasien perawatan total dengan penyakit kronis. Integritas kulit dinilai menggunakan Braden score sedangkan kondisi pasien dinilai melalui pengamatan. Temuan penelitian ini menunjukkan bahwa memandikan pasien dengan minyak zaitun dan air hangat memiliki efek menenangkan pada pasien dan mencegah kerusakan integritas kulit. Dengan demikian, penggunaan minyak zaitun dan air hangat dalam intervensi mandi dapat mencegah risiko kerusakan integritas kulit pada pasien perawatan total dengan penyakit kronis. 
Pele, M. and Waluyo, A.| Use of olive oil and warm water in bathing intervention in preventing risk of skin...

Kata kunci: integritas kulit, intervensi mandi, mandi air hangat, risiko kerusakan integritas kulit risiko

\section{INTRODUCTION}

The risk of skin integrity damage is a state of a person's skin, which is at risk of undesirable changes (Wilkinson, 2007). According to Kamitsuru \& Herdman, (2014), the risk of skin integrity damage is a condition of the skin that is susceptible to changes in the epidermis and/or dermis, which can endanger health. Unwanted changes such as dry, scaly skin, the onset of dermatitis, pruritus, and pressure sores (Semeltzer and Bare, 2013). Interference and changes in the integrity of the skin can cause a decrease in the quality of life of patients due to itching and discomfort. Dry skin causes many skin disorders such as dry dermatitis. The condition of these patients requires more time in the hospital to do additional treatment related to the disease (Iiyama \& Kawahira, 2008). Skin changes can harm a person's quality of life. Changes in skin appearance can significantly influence psychosocial well-being (Bianchi et al., 2015).

According to Wilkinson (2007), risk factors that cause damage to skin integrity include moisture, changes in nutritional status, physical immobilization, treatment, changes in skin turgor, changes in metabolic state and decreased immunity. Other factors are age, changes in the environment, and the effects of the disease (ElSoussi \& Asfour, 2016 ). Patients in the intensive care unit (ICU) have a higher risk of skin colonization and infection by multi-resistant organisms (MDROs) due to significant comorbid/ confounding factors, immunodeficiency, antibiotic exposure and damage to skin integrity related to invasive procedures given in patients (ElSoussi \& Asfour, 2016 ). Therefore, effective personal hygiene in patients in the ICU is considered very important because poor hygiene can increase the risk of infection.

Assessment of the integrity of the skin is an essential part of treatment and must be done when the patient is admitted to the hospital, and every day depends on the individual's circumstances.

High-risk patients need a skin examination at least once per shift. It is crucial for nurses to know the factors that can increase the risk of skin integrity damage. There is considered the same as when nurses apply six rights to administer drugs each time they give medicines to reduce the risk of errors. By using the basics of the following treatments, patients are protected from further injury and the risk of hospital-acquired conditions, such as infections, skin tears, and reduced pressure injuries. The basics of skin care include skin assessment, skin care, massage, pressure relief, nutrition and hydration, and education and communication (Fraser, 2017). This case study to describe using olive oil and warm water in bed bath actions in preventing the risk of skin integrity damage in total care patients with chronic disease.

\section{METHOD}

This case study was conducted in the Intensive Care Unit Ciptomangunkusumo Hospital Jakarta on 12-14 October 2018. Skin integrity assessed by Braden score and patient condition determined by researcher observations. The patient is Mr. S is 69 years old with ketoacidosis diabetic (diabetic mellitus type 2) and chronic kidney disease. Patients admitted to the hospital because of weakness for 15 days before. Patients have treated with diabetes mellitus medication since 33 years ago with lantus $1 \times 18$ IU and numaleg 3x 18 IU. The geriatric out-patient department has controlled patients. In 2014, the patient fell and was hospitalized for three days and had stroke diagnoses. In 2015 patients got a hypertensive disease and taking Adalat medicine 1x1 tablet. Patients assisted in walking, bathing, and also eating at home. The patient was hospitalized since 30 days ago and doing the intubation in the ICU on October 5, 2018. The consciousness was compos mentist, NGT attached, BP 115/45, HR 76, temperature 37, RR 18, skin condition felt dry, rough and slightly scaly. The 
area of the buttocks is explored moist. The patient's care plan was to take hemodialysis with urea 79 , creatinine 1.90 , and GFR 35.2 , but patients and families refused. The area of the patient's back looks reddish and moist. The folds of the thighs and armpit appear to be a layer of dead skin or dirt that is slightly thickened. Patients sometimes feel uncomfortable and said a little itchy on the skin, so make her difficult to sleep. The patient was immobilized and got bathing by the nurse every morning using. Patients also receive laxis $2 \times 40 \mathrm{mg}$ intravenously to reduce fluid load due to chronic kidney disease factors.

The application of olive oil to the bathing of the patient begins with preparing the equipment, namely olive oil, washcloth, a container of warm water and a soft towel. Bathing preparation is done by opening and releasing the pampers in the patient and seeing whether the patient is defecating or not. After that, the nurse opens the patient's clothes and then closes it with a bath blanket. The process is to clean the patient's face using only warm water. Then apply olive oil 2-3 drops especially in areas that have the possibility of accumulation of dead skin cells and sweat that is quite a lot such as the folds of the thighs, perineal, armpits and silence briefly for about 510 minutes. On the part that is not the fold area, immediately drop the olive oil on the palm as much as 3-4 drops then rub it gently while doing massage. After rubbing or massaging it is continued by rinsing it using warm water, including in the soft folded areas so that the dead skin layer will be released. Then the equipment is cleaned up and allows the patient to rest.

\section{RESULT}

The value of the Braden score on October 12,2018 , is 12. After an intervention, the cost of the Braden score becomes 14 on October 14, 2018. Thee results of observations by nurses, the patient's condition is calmer, not agitated, fast asleep, and is in vital signs after the intervention. The act of bathing patients with olive oil and warm water provides comfort, reduces itching and prevents dry skin in patients, especially patients who already have risk factors for skin in- integrity problems such as Mr. S. A combination of warm water that stimulates vasodilation so that it increases blood flow, mainly peripheral blood pressure which delivers oxygen and nutrients needed to reach outer areas with olive oil which cleanses dead skin and provides moisture and skin health with linoleic acid. Nurses can do bathing activities in patients every morning both in the ICU and in the usual care room. The response to Mr. S after taking a bath using olive oil is to fall asleep immediately. Based on reports from nurses, that S hasn't slept well like this while in the ICU. Patients have difficulty sleeping and are often awakened by slight stimuli, both sound, and touch.

\section{DISCUSSION}

The condition of patients with chronic disease and immobilization is a risk factor for disruption of skin integrity. The position of immobilization in patients who are not regularly and routinely replaced is very risky for pressure sores (Asmadi, 2008). The condition of CKD patients is very susceptible to dry skin problems and xerosis. It is caused by a decrease in the size of the eccrine sweat glands and sebaceous glands undergoing atrophy and occurs due to side effects from the use of diuretic therapy. In situations like this, patients are advised not to bathe over because the skin can become irritated due to the accumulation of soap on the surface (Gagnon \& Desai, 2013 ). The mass of uremic granules on the skin after the patient sweats will trigger severe itching ((Semeltzer and Bare, 2013). The age of Mr. S has entered the elderly. Elderly patients with the epidermis layer become thinner, collagen decreases in the dermis layer, so the skin becomes less elastic and prone to tearing or sliding. Besides, because the support system began to decline (Bianchi, et al., 2015).

Skincare that is often done by nurses in patients to maintain skin integrity is bathing. Bathing is a washing process designed to remove debris/dirt from the surface of the skin through mechanical action, flushing particles, and through a direct chemical reaction (Vogeli, 20 08). Bathing is a crucial nursing intervention that is associated with quality of life and quality 
of care. Bathing has been known to affect improving patient well-being and comfort. Bathing also has an essential function to maintain skin integrity and personal hygiene, which in turn will prevent infection and disease (Groven et al., 2017). Bathing every day in chronic patients can improve hygiene and maintain skin integrity, increase comfort, improve health outcomes, relax, stimulate circulation, and reduce pyrexia. Personal hygiene is also strongly related to one's self-esteem and well-being (El-Soussi \& Asfour, 2016 ).

Interventions bathing and maintaining skin moisture in patients are basic nursing actions for nurses to prevent damage to skin integrity and improve comfort in patients. Swimming is a nursing intervention intended to support hygiene, thermic regulation, microbiotic reduction, satisfaction, comfort, and convenience. To carry out procedures effectively and safely, professional nurses must identify and minimize potential disruptions, because changes in position in the bed, changes in water temperature and environment and clinical conditions themselves can have an impact on the hemodynamic response shown by the patient (Da Silva et al., 2016).

In patients with chronic disease conditions and extended bed rest have a higher risk of damage to skin integrity. The focus of the act of bathing the patient is the buildup of dead skin in the folds such as the armpit, thighs, perianal which has a high level of humidity and allows the accumulation of microorganisms and the secretion of apocrine sweat glands. Besides, the area that is the site of the risk of pressure sores such as the heel, buttocks, elbows, and sacrum is very important to be considered to prevent the occurrence of pressure sores. Nursing actions also include planning fulfillment of nutrition for patients to improve nutritional status and achievement of fluids to maintain the body's fluid and electrolyte balance and prevent dehydration and decrease in skin turgor which affects skin damage. Bathing is usually done by nurses, in general, is a traditional bath that uses water, soap, and towels to dry the patient. The essence of care and protection of the skin in bathing patients with skin problems is mild soap or using a substitute for soap, then rinsing the area entirely and drying it with a soft cloth (Semeltzer and Bare, 2013).

Making sure the skin is cleansed, thoroughly dried, and moistened every day will reduce the risk of excoriation and help keep the skin in good condition. Using non-soap cleansers will help protect the acid coat and prevent the skin from drying out, while moisturizers provide hydration to the skin and help to stay in good condition. The skin $\mathrm{pH}$ is around 5.5, while generally, alkaline soap has a $\mathrm{pH}$ of about 8 or $9.3 \mathrm{pH}$. Alkaline can create an environment for the growth of opportunistic bacteria that can cause infection, especially if the skin is disrupted. Besides, if the patient wet the bed, the nurse must ensure that the continuity is checked and changed regularly and the exposed skin is cleaned, altered and dampened to reduce risk of painful moisture lesions and excoriations. For patients with high BMI, be sure to pay special attention to the folds of the skin. Nurses also need to pay attention to the pressure used to clean fragile skin because this can cause the skin to tear and/or bruise if too much force is applied (Holloway \& Jones, 2005).

The condition of Mr. S who is at risk of damage to skin integrity is caused by the state of immobilization experienced, the age of patients who have entered the elderly and CKD which also contribute to the risk of damage to skin integrity. Therefore, consideration is needed from the nurse to determine the right steps in planning to bathe the patient. The interventions carried out are expected to provide comfort and well-being to patients. In this situation, the traditional way of bathing, which is usually done using soap needs to be considered by the nurse. According to Voegeli (2008), nursing actions that bathe patients using soap and water and drying with towels have a significant disturbing effect on the skin as a barrier. Some skin problems are greatly aggravated by soap and water, and bathing routines are modified according to conditions. The skin is very susceptible to damage by chemicals and trauma. The friction of the towel, if applied firmly, is sufficient enough to produce a rapid inflammatory response that causes existing le- 
sions to spread and expand (Semeltzer and Bare, 2013). Interventions that can cleanse and moisturize the skin without using soap are a challenge for nurses.

One intervention that can be applied is the use of olive oil. Olive oil comes from the extraction of olives. Olive oil contains linoleic acid, which is defined as an essential fatty acid for humans that is beneficial for skin health by overcoming problems related to scaly skin, eczema, and dry skin. Olive oil helps with pressure problems associated with thrombotic and vasoconstriction issues, especially in the peripheral circulation system (Lin, Zhong, \& Santiago, 2017). Olive oil has a hard nature to remove the remains of dead skin but is soft for the skin. Aroma olive oil is also calming for patients.

The thing that could potentially be a challenge for nurses is cleaning the skin of the patient without using soap but still having a clean effect. It must be ensured that the lifting of dead skin, especially in the intertriginous/folded area is still moist and comfort for the patient.

\section{REFERENCES}

Asmadi. 2008. Konsep dan Aplikasi Kebutuhan Dasar Klien. Jakarta: Salemba Medika

Bianchi, J., Page, B., \& Robertson, S. (2015). Skin Integrity In The Older Person Assessment And Management To Optimise Skin Health: Skin integrity Focus. published November 2015

Da Silva, C. J. B., dos Santos Silva, M. É., Reis, F. F., de Miranda, G. C. O., dos Santos, L., $\&$ de Lima, D. V. M. (2016). Bed bath for infarcted patients: crossover of the hydrothermal control $40^{\circ} \mathrm{C}$ versus $42.5{ }^{\circ} \mathrm{C}$. Online Brazilian Journal of Nursing, 15(3), 341-350.

El-Soussi, A. H., \& Asfour, H. I. (2016). Examining bed-bath practices of critically ill patients. Journal of Nursing Education and Practice, 6(12).

Fraser, B. (2017). Aging skin and the importance of skin integrity assessment. https://healthtimes.com.au

Gagnon, A. L., \& Desai, T. (2013). Dermatolo-
For that, the nurses need guidance how to use a combination of olive oil and warm water effectively in removing impurities on the patient's skin so that it can be reducing itching, reducing dryness, and increasing patient comfort.

\section{CONCLUSION}

In several studies, bathing with soap has been found to have a damaging effect to the patient's skin because of its ingredient such as lauric sodium sulfate. It irritant causes the skin to dry out. Bathing is a nursing intervention that has been part of nursing care since the patient entered the hospital until the patient left the hospital. Use of olive oil and warm water in bathing intervention can be preventing the risk of skin integrity damage in total care patients with chronic disease.

gical diseases in patients with chronic kidney disease. Journal of nephropathology, 2 (2), 104.

Groven et al.,. (2017). How Does Washing Without Water Perform Compared To The Traditional Bed Bath: A Systematic Review. BMC Geriatric (http:// creativecommons.org/publicdomain

Holloway, S., \& Jones, V. (2005). The importance of skin care and assessment. British Journal of Nursing, 14(22), 1172-1176.

Kamitsuru, S., \& Herdman, T. H. (2014). NANDA International, Inc. NURSING DIAGNOSES: Definitions \& Classification.

Iiyama, J. I., \& Kawahira, K. (2008). Effects of bathing in warm water with added glycerin on skin conditions and prevention of skin disorders in patients with severe motor and intellectual disabilities. The Journal of The Japanese Society of Balneology, Climatology, and Physical Medicine, 71(3), 173-179.

Lin, T. K., Zhong, L., \& Santiago, J. (2017). Anti-inflammatory and skin barrier repair 
effects of topical application of some plant oils. International journal of molecular sciences, 19(1), 70.

Voegeli, D. (2008). The effect of washing and drying practices on skin barrier function. Journal of Wound Ostomy \& Continence Nursing, 35(1), 84-90.
Semeltzer, S. C. and Bare, B. G. (2013). Keperawatan Medikal Bedah Brunner \& Suddarth. Edisi 12. Alih Bahasa, Devi Yulianti, Amelia Kimi. Jakarta : EGC.

Wilkinson, J.M,. (2007) .Buku Saku Diagnosis Keperawatan dengan intervensi NIC dan Kriteria Hasil NOC.Jakarta: EGC 